\title{
Coğrafi Bilgi Sistemleri (CBS) Tabanlı Çok Kriterli Karar Analizi (Çkka) Kullanılarak, Van ili Merkez İlçelerinin Kentsel Tașkın Duyarlılık Değerlendirmesi, Van / Türkiye
}

\author{
Urban Flood Susceptibility Assessment of Central Districts of Van \\ Province, Turkey, Using Geographic Information System (GIS)-Based \\ Multi Criteria Decision Analysis (MCDA)
}

\author{
LEVENT SELÇUK ${ }^{1 *}$, AZAD SAĞLAM SELÇUK ${ }^{1}$, DILAN KASAPOĞLU1

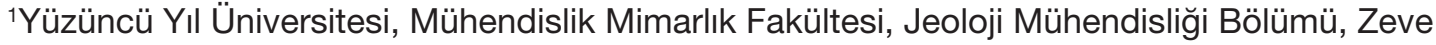 \\ Kampüsü, Tuşba 65080 Van, Türkiye
}

Geliș (received) : 30 Haziran (June) 2015

Kabul (accepted) : 22 Ocak (January) 2016

\section{öz}

Van (Türkiye) ili su baskınlarının sıklıkla gözlendiği șehirlerimizden birisidir. Son 60 yıllık istatistiksel çalıșmalar içerisinde Van ili ve ilçelerinde toplam 166 su baskını olayı meydana gelmiștir. Bu durumun en önemli nedenleri; sonbahar ve ilkbahar aylarında gözlenen așırı yağıșlar, özellikle karların erimesiyle birlikte yeraltı su seviyesinin yüzeye yakın olduğu doygun zemin koșulları, yerleșim alanlarının kapalı yüzeyler yaratması ve yetersiz kanalizasyon alt yapısıdır.

Bu çalıșmanın amacı coğrafi bilgi sistemi (CBS) tabanlı çok kriterli karar analizi (ÇKKA) kullanılarak, Van merkez ilçelerinde kentsel tașkın duyarlıı̆ının değerlendirilmesidir. Çalıșmada olușturulan model 6 ayrı faktörü içerir. Bunlar; litoloji, yeraltı su tablası derinliği, eğim, yükseklik, drenaj kanallarına olan mesafe ve alan kullanımıdır. Tașkın duyarlıık haritası tüm tanımlı faktörlerin birbiri ile kıyaslanmasından olușan karșılaștırma matrisi kullanılarak elde edilmiștir. Haritanın güvenilirliği ve doğruluğu, söz konusu merkez ilçelerinde meydana gelen tașkın olaylarının karșılaștııımasıyla değerlendirilmiștir. Așırı yağıșlara bağlı olarak gerçekleșen tașkın olayları, harita içerisinde tanımlı yüksek duyarlı alanlar içerisinde yeralmaktadır. Duyarlıık haritasına göre, Van ili İpekyolu merkez ilçesi, diğer ilçelere göre çok daha yüksek tașkın potansiyeline sahiptir. Yüksek duyarlıık genellikle düșük eğimli, genel olarak geçirimsiz litolojik birimlerin yeraldığı alanlar olarak dikkat çekmektedir. Dolayısıyla, olası tașkınlardan korunmak amacıyla dere yataklarının ve kanalizasyon alt yapı sistemlerinin iyileștirilmesi en etkin yöntemler olarak görülmektedir.

Anahtar Kelimeler: Coğrafi bilgi sistemi (CBS), çok kriterli karar analizi (ÇKKA), duyarııık, tașkın, Van.

\begin{abstract}
Van (Turkey) is one of the easily affected cities in the flooding. According to the latest 60-year statistical data, a total of 166 flood events were occurred in Van province and its districts. The most important reason for the flooding is the impermeable cover of residential areas and poor substructure systems within heavy rainfall in the spring which ground water level is close to the surface due to melting of snow.
\end{abstract}

The scope of this study is to evaluate the flood susceptibility of the central district of Van, using multi-criteria decision analysis (CPL), and geographic information systems (GIS). The susceptibility model developed in this study contains six different factors. These are: lithology, the depth of groundwater table, distance to the discharge channels, slope, elevation (above mean sea level) and land-use. The susceptibility assessment is conducted by using a comparison matrix where all identified criteria of GIS layers are compared against each other. The acceptability

${ }^{*}$ L. Selçuk

e-posta: Iselcuk@yyu.edu.tr 
and reliability of the model was determined using historical events. All of these events plotted over the model showed that there is a remarkable coincidence with high susceptibility areas. The flood susceptibility model shows that ipekyolu, central district of Van city, has much more flood hazard potential than those of other districts. High susceptibility to flooding in the study area is mainly related with flat terrain features so that the area has a low slope angle, impermeable lithology and the presence of urban stream channels with poor maintenance plan. Therefore, in order to prevent the possible flooding, site planning, improving the stream beds and substructure systems should be effectively integrated in potential areas.

Keywords: Geographical information system (GIS), multi-criteria decision analysis (MCDA), susceptibility, flood, Van.

\section{Giriș}

$\mathrm{Su}$ baskınlarından etkilenen afetzede sayıları ülkemiz genelinde değerlendirilmeye alındığında, Van ili ve ilçeleri tașkın olaylarından en çok etkilenen yerleșim alanları içerisinde yeralır. Sonbahar ve özellikle ilkbahar aylarında șiddetli yağıșlar, Van ili ve ilçelerinde 1950-2008 yılları arasında 166 ayrı su baskınına neden olmuștur. AFAD (2008) tarafından rapor edilen bu olaylardan etkilenen toplam afetzede sayısı ise yaklașık 1480'dir. Son 15 yılık süreç içerisinde ise (2000-2015) sadece merkez ilçelerde meydana gelen su baskını sayısı yaklașık 30 civarındadır. $\mathrm{Bu}$ istatistiksel veri her yıl farklı yağıșlarla birlikte en az iki su baskını olayının șehir merkezinde yașandığını göstermektedir.

Tașkın olayları bölgenin meteorolojik özellikleri ve topoğrafik yapısıyla yakından ilișkilidir. Her ne kadar ana etmen bölgenin yağıș karakteri, jeolojik ve jeomorfolojik koșullar olsa da, özellikle dere yataklarındaki kontrolsüz yapılaşma, inşaat hafriyatı ve yetersiz altyapı sistemleri gibi yanlış arazi kullanımı sonucu doğan ve hidrolik dengeyi bozan insan aktiviteleri de önemli etkenler arasındadır. Özellikle Van ili gibi hızlı büyüyen şehirlerde, artan nüfus atık suların artmasına ve buna bağlı olarak așırı yağıșlarla birlikte kentsel tașkın olaylarının gelișmesinde ana etkendir. Yüzeyde suyun akıșını kontrol eden yollar ve kaldırım, ayrıca zeminin büyük bir kesimini kapsayan binalar ile engellenen doğal drenaj alanları, suyun akıșını kısıtlayarak tașkının etkisini arttırmaktadır (Harris ve Rantz, 1964; Konrad ve Booth, 2002; Konrad ve Booth, 2005; Fernandez ve Lutz, 2010). Tașkın olaylarının azaltılmasında kent alanlarındaki atık suların tahliyesi ve kanalizasyon alt yapısı önemli rol oynamaktadır.
Kent nüfusunun artıșı ile birlikte söz konusu etkinin şiddeti de artmaktadır. Bu nedenle, olası tașkın duyarlılığının değerlendirilmesinde, meteorolojik koșulların yanında, yeraltı su derinliği, jeolojik durum ve kentin bu etki üzerindeki rolü de dikkate alınmalıdır. Özellikle yoğun yerleşim alanlarında tașkının etkisi çok daha șiddetli hissedilmektedir. Çünkü etkilenen alanlar genellikle drenaja kapalı yüzeyler ve yetersiz yeraltı drenaj kanallarını içermektedir. Ilımlı yağıșlarda bile, kanalizasyon alt yapısında yüksek debili akımlar söz konusu olabilmektedir. Așırı yağıșlara meyilli alanlarda bu durum, riskin artmasında önemli bir olgudur.

Meteorolojik verilere bağlı olarak olası tașkınların tahmini günümüzde sınırlı iken, kentsel tașkın duyarlılık haritaları veya modelleri olası tehlikenin değerlendirilmesinde ve kentin gelișiminin planlanmasında önemli veriler sağlamaktadır. Ayrıca söz konusu modeller genellikle tașkına meyilli alanların drenaj altyapı intiyaçlarını belirlemek içinde kullanılmaktadırlar (Büchele vd., 2006). Bu kapsamda Coğrafi Bilgi Sisteminin (CBS) kullanımı duyarlııı haritalarının olușturulmasında oldukça önemli bir araçtır. Çünkü CBS, doğal afetlerin değerlendirilmesinde gerekli olan topografik arazi bilgilerini analiz eder ve fazla sayıda kriteri çok sayıda arazi verisi ile değerlendirmeye olanak tanır. CBS ile birlikte çok kriterli karar analizinin (ÇKKA) birlikte kullanımı, karmașık karar problemlerin, tasarım, değerlendirme ve alternatif kararların çözüm teknikleri üzerine zengin bir koleksiyon sunar (Malczewski, 2006). Özellikle doğal afetlerin ve jeolojik çevrenin değerlendirilmesinde, CBS ve ÇKKA yaklașımlarının kullanılması birçok çalıșmada önerilmektedir (Ayalew vd., 2004; Gamper vd., 2006; Fernandezve Lutz, 2010; Dai vd., 2001; Joerin vd., 2001; Kolat vd., 2006; Selçuk, 2013). 
$\mathrm{Bu}$ çalıșmanın amacı CBS tabanlı ÇKKA kullanılarak, Van merkez ilçelerinde taşkın duyarlılık modelinin olușturulmasıdır. Çalışmada oluşturulan model 6 ayrı faktörü içermektedir. $\mathrm{Bu}$ faktörler litoloji, yeraltı su tablası derinliği, eğim, yükseklik, kanal mesafesi ve alan kullanımıdır. Duyarlılık modeli tüm tanımlı kriterlerin birbiri ile kıyaslanmasından olușan karșılaștırma matrisi kullanılarak elde edilmiștir. Modelin güvenilirliği ve doğruluğu, söz konusu merkez ilçelerinde meydana gelen olayların model ile karșılaștırılmasıyla değerlendirilmiștir.

\section{ÇALIȘMA ALANI}

Van ili merkez ilçeleri, yaklașık 1650 m ile 1770 m kotları arasında, Van Ovası üzerinde yer almaktadır. Ortalama yükseklik farkı (relief) 120 m'dir. Yerleșim alanının batı sınırını olușturan Van Gölü kıyısında $1^{\circ}$ ile $2^{\circ}$ olan eğim değeri, doğu ve güney kesimlerde $6^{\circ}$ ile kısmen $16^{\circ}$ değerlerine ulașmaktadır. Bu açıdan, Van ili merkez ilçeleri genel olarak düșük eğimli geniş düzlüklerden oluşmuş bir topografyaya sahiptir.
Çalışma alanı İpekyolu, Tuşba ve Edremit merkez ilçelerini kapsamaktadır (Şekil 1a). Yaklașık $116 \mathrm{~km}^{2}$ içerisinde yer alan ilçe merkezlerindeki toplam nüfus 538.801' dir (TiK, 2015). Bu nüfusun \%51'i eski yerleșim alanının da içinde bulunduğu İpekyolu ilçesindedir. Söz konusu ilçe yüksek katlı yapılașmanın yoğun olarak gözlendiği merkez konumundadır. İpekyolu ilçesinin nüfus yoğunluğu, topografyası ve alan kullanımı Erek Dağı eteklerinden Van Gölü'ne doğru değișkendir. Edremit ve Tușba ilçeleri ise göreceli olarak düșük katı yapılașmanın hâkim olduğu konut alanlarını içermektedir. Tarihsel süreç içerisinde, kent yașamı ipekyolu (D300 Devlet Karayolu) ile demiryolu arasında gelișmeye bașlamıștır. Süreç içerisinde kent ipekyolunun sağladığı ulașım kolaylıkları ile beraber karayoluna ve karayolu aksı boyunca yayılmasını sürdürmüștür.

Bölgenin iklim durumu denizlerden uzak ve yüksek olmasından dolayı şiddetli karasal iklim tipidir. Bu iklim kendini özellikle çok soğuk ve uzun kıșlarla belli eder. Sert ve uzun kıșların hüküm sürdüğü bu yüksek bölüm içinde, nispeten
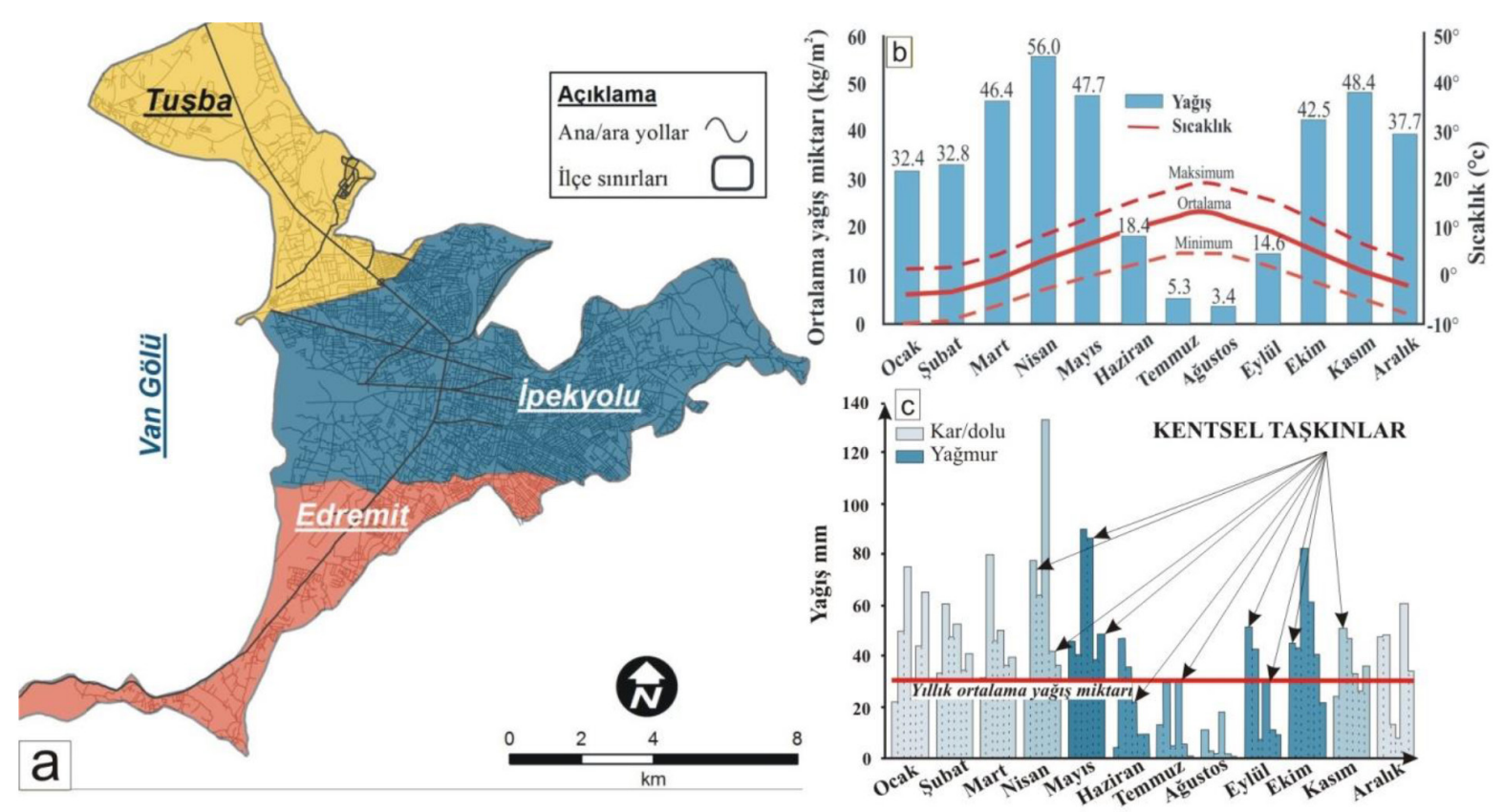

Şekil 1. a) Çalıșma alanının yer bulduru haritası, b) Van il merkezi için ortalama yağıș miktarı ve sıcaklık eğrileri, c) 2008-2013 yılları arasında meydana gelen tașkın olayları.

Figure 1.a) Location map of the study area, b) Annual average precipitations and temperature lines of Van Province,c) several flood events occurred between 2008 and 2013 years. 
alçak kısımlar, özellikle Van gölü kıyılarında yer alan ovalar, kıșların çok șiddetli olmadığı çukur alanlardır. Bu ovaların en büyüğü, merkez ilçe yerleșim alanlarının da üzerinde bulunduğu, Van Gölü'nün doğusunda, göl ile Erek Dağı arasında uzanan ve yüksekliği 1650-1850 m'ye varan Van Ovası'dır. Van ovasında kıșlar, gölün yumușatıcı etkisinden dolayı Doğu Anadolu Bölgesi'ndeki diğer alanlar kadar șiddetli geçmediği gibi, yaz ayları sıcaklık değerleri de yüksek değildir (Kalelioğlu, 1991). 1950-2014 yılları arası istatistiksel verilere göre, yılın en soğuk ayı olan ocak ayının ortalama sıcaklığı $-3.5^{\circ} \mathrm{C}$, en sıcak ay olan temmuz ayının ortalama sıcaklığı $22^{\circ} \mathrm{C}$ kadardır (MGM, 2015). Karasal tip yağıș rejiminin görüldüğü ovada, kutupsal cephenin oluștuğu ve konvektif yağıșların bașladığı ilkbahar, yııın en yağıșlı mevsimidir (Şekil 1b). Yıllık ortalama yağıș miktarı 385.7 kg/m²'dir. Karasal yağıș rejiminin görüldüğü ovada, yıllık yağıșın \% 28.5' i kış, \% 37.5' i ilkbahar, \% 6.5' i yaz ve \% 27.5 ' i sonbahar aylarında meydana gelir.

Van Ovası'nı kateden en önemli drenaj hattı Engüsner (Değirmendere) Çayı'dır. Dere kuzeydoğudan bașlayarak ovanın kuzey kesimi boyunca devam eder. Ova içerisindeki hattı ise Akköprü Deresi'dir. Ovanın güney kısmında ise Erek Dağı etekleri boyunca devam eden Kurubaș (Doni Çayı) Deresi bulunur. Bu dere yan kollara ayrılarak ovanın güneydoğu kenarını izler. Bu ana dere yatakları ile birlikte ilkbahar döneminde karların erimesiyle olușan mevsimlik dereler tașıdıkları sedimanlar ile ovadaki alüvyon birikim sürecini günümüzde sürdürür. Son yıllarda kentin gelișimine paralel olarak, dere yatakları etrafında gelișen mahallelerdeki atıklar ve akarsuyun getirdiği blok boyutu malzeme, dere yataklarının drenaj kapasitesini etkilemiștir. Bu durumun en önemli örnekleri 1 Ekim 2008 ve 3 Kasım 2009 tarihlerinde anlık yağıșlara bağIı olarak gelișen Tușba ve İpekyolu ilçelerinde yașanan ani tașkın olaylarıdır (Şekil 2). 1 Ekim 2008 tarihinde Akköprü ve Kurubaș dereleri tașmıștır. Tușba ilçesinde İstasyon, Akköprü, Beyüzümü, Altıntepe, A. Gazi mahalleleri, İpek yolu ilçesinde ise Selimbey, Yenimahalle, Karșıyaka, Seyyit Fehim Arvasi, Cevdetpașa Mahalleleri ve yakın çevresi, Edremit ilçesinde ise Süphan mahallesi tașkından sıklıkla etkilenen yerleșim alanlarıdır (Şekil 3). 3 Kasım 2009 tarihinde Akköprü Deresi'nin tașmasına bağlı olarak, dere yatağında bulunan Altıntepe mahallesindeki yaklașık 20 konut ve geniș bir arazi su altında kalmıștır.

Yaklașık son 15 yıllık dönemde rapor edilen tașkın olayları incelendiğinde, afetlerin merkez ilçeler için farklılık gösterdiği görülmektedir. Çizelge 1'de görüldüğü gibi, İpekyolu ve Tușba merkez ilçeleri, Edremit merkez ilçesine göre söz konusu afetlerden daha fazla etkilenmektedir. Bu durum, Edremit ilçesindeki yerleșim alanlarının büyük bir kısmının ilçenin güney ve güney doğusunda, yüksek kesimli alanlarda yeralmasından kaynaklanır (Şekil 3 ve 4). Yüksek eğimli alanlarda yağmur suları eğim boyunca yüksek hız ile akarken, çok daha düşük eğime sahip Tușba ve İpekyolu merkez ilçelerinde șiddetli yağıșlar drenaj sistemlerini aşarak yüksek kapasitede yüzey akıșlarına neden olmaktadır. Son yıllarda yașanılan su baskını olayları incelendiğinde, söz konusu olayların genellikle aylık ortalama yağıșların üzerinde, aşırı yağışlara bağlı olarak meydana geldiği görülmektedir (Şekil 1c ve 5a). 2013 ve 2014 yılları Nisan ve Mayıs aylarında, șehir yașamının yoğun olduğu İpekyolu ilçesinde, yașanılan su baskınları șehir yașamını olumsuz yönde etkilemiș ve Cumhuriyet mahallesinde birçok işyeri zarar görmüştür. Van merkez ilçeleri için 1980-2015 yıllarına ait yağıș verileri dikkate alındığı zaman, 1984 yılı Mayıs ayında en fazla yağıșın meydana geldiği görülmektedir. Söz konusu bu yağıș değerinin yineleme dönemi 36 yıl, olasılık değeri ise yaklașık \% 1'dir. Bölge için en yüksek yağıș değerin kısa dönem içerisinde olușma olasılığı düșük olsa da, aylık ortalama değerlerin üzerinde meydana gelebilecek yağıșların olasılığı oldukça yüksektir. Örneğin, 3 yıllık yineleme periyodu içerisinde Nisan ve Mayıs ayları için elde edilebilecek olan yaklașık yağıș değerleri sırasıyla 64 ile 60 mm'dir. Bu değerler söz konusu aylar için ortalamanın (ortalama; $56 \mathrm{~mm}$ ve $48 \mathrm{~mm}$ ) üzerindedir (Şekil 5b). Aylık ortalama yağıșlar için gerekli dönüș periyodu ise 2.1 yıldır ve olușma olasılığı yaklașık \% 49' dur.

Diğer taraftan yașanılan su baskınlarının șiddetini arttırıcı yönde rol oynayan, yeraltı su seviyesi ve zemin doygunluğu önemli parametreler 


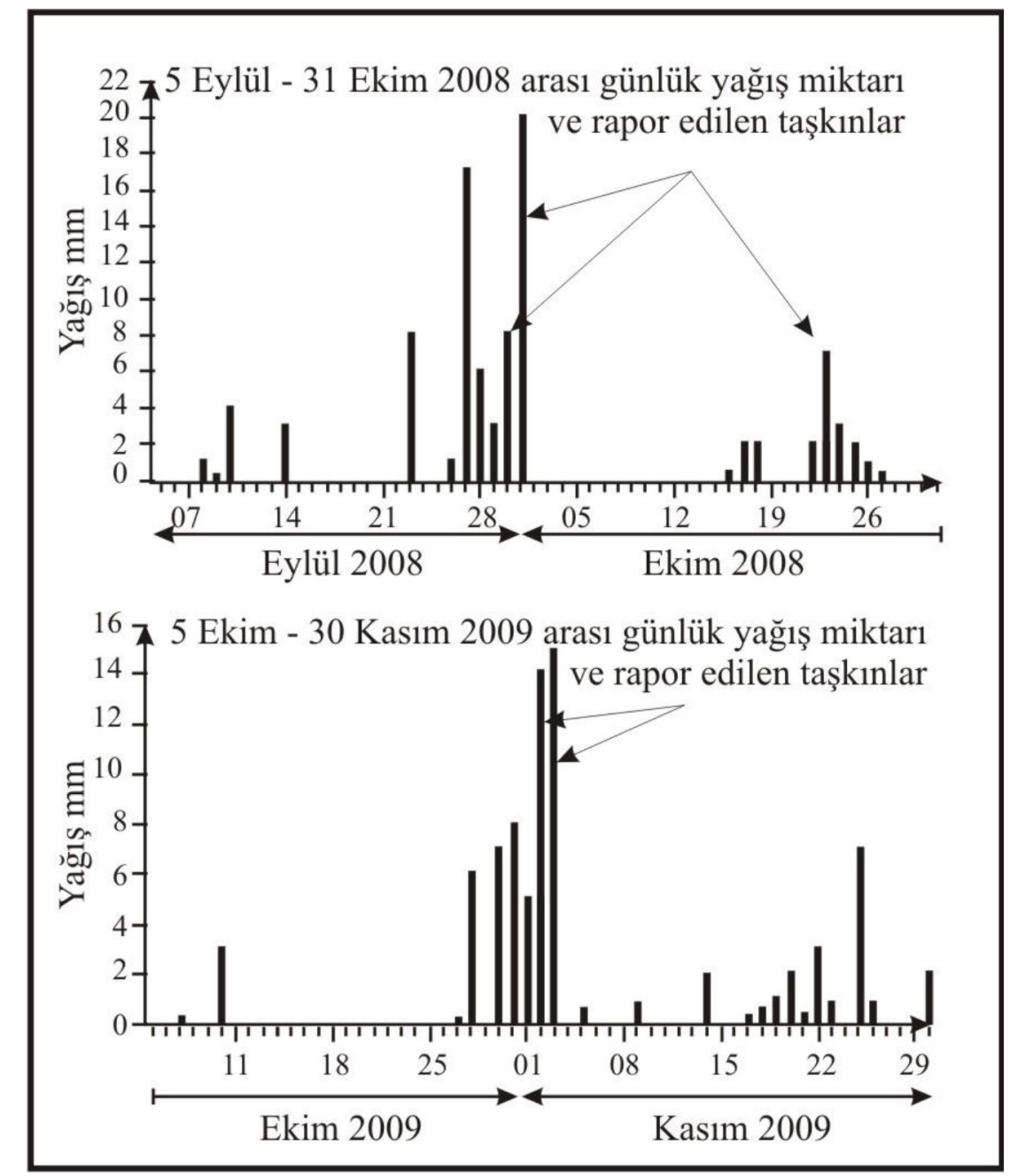

Şekil 2. 2008 ve 2009 güz döneminde günlük yağıș miktarları ve rapor edilen tașkınlar.

Figure 2. The daily rainfall amounts and the flood events reported in the fall of 2008 and 2009 years.

olsa da, özellikle yaz ayları sonrası anlık yağıșlara bağlı olarak yașanılan tașkınlarda şehir yaşamını etkilemektedir. Yaz aylarının ortalama yağıș yükseklikleri değerlendirildiğinde Eylül ve Ekim ayları sonlarında henüz zeminin doygunluğa ulașması mümkün değildir. Şekil 2'de görüldüğü gibi, 1 Ekim 2008 ve 3 Kasım 2009 tarihlerinde merkez ilçelerde meydana gelen tașkınlar yeraltı su seviyesinin düșük veya zeminin suya doygun olmadığı anlık yağıșlara bağı olarak gelișmiștir. Söz konusu afetler altyapının yetersiz veya zeminin yağıșa kapalı olduğu alanlarda, anlık yağıșlara bağlı olarak sıklıkla yașanmaktadır. Dolayısıyla bölgede yașanılan tașkın olayları, jeolojik ve hidrojeolojik koșullar dıșında, kontrolsüz yapılașma ve yetersiz altyapı sistemleri gibi yanlıș arazi kullanımına sebep olan uygulamalardan da önemli derecede etkilenmektedir.

\section{YÖNTEM}

Tașkın duyarlılık modelinin olușturulmasında kullanılan akıș șeması Şekil 6'da verilmiștir. Yöntemin ilk așaması, kentsel tașkın potansiyelinin değerlendirilmesinde etkin faktörleri ve bu faktörlerin veri analizlerini içerir. Bu kapsamda mahalle bazında 1/1000 ölçekli hâlihazır imar paftalarından yararlanılarak, çalışma alanı için detaylı dijital yükseklik modeli (DEM) olușturulmuștur. DEM kriging interpolasyon yöntemiyle $1 \mathrm{~m} \times 1 \mathrm{~m}$ hücre boyutunda yüksek çözünürlük ile üretilmiştir. Söz konusu yükseklik modeli 

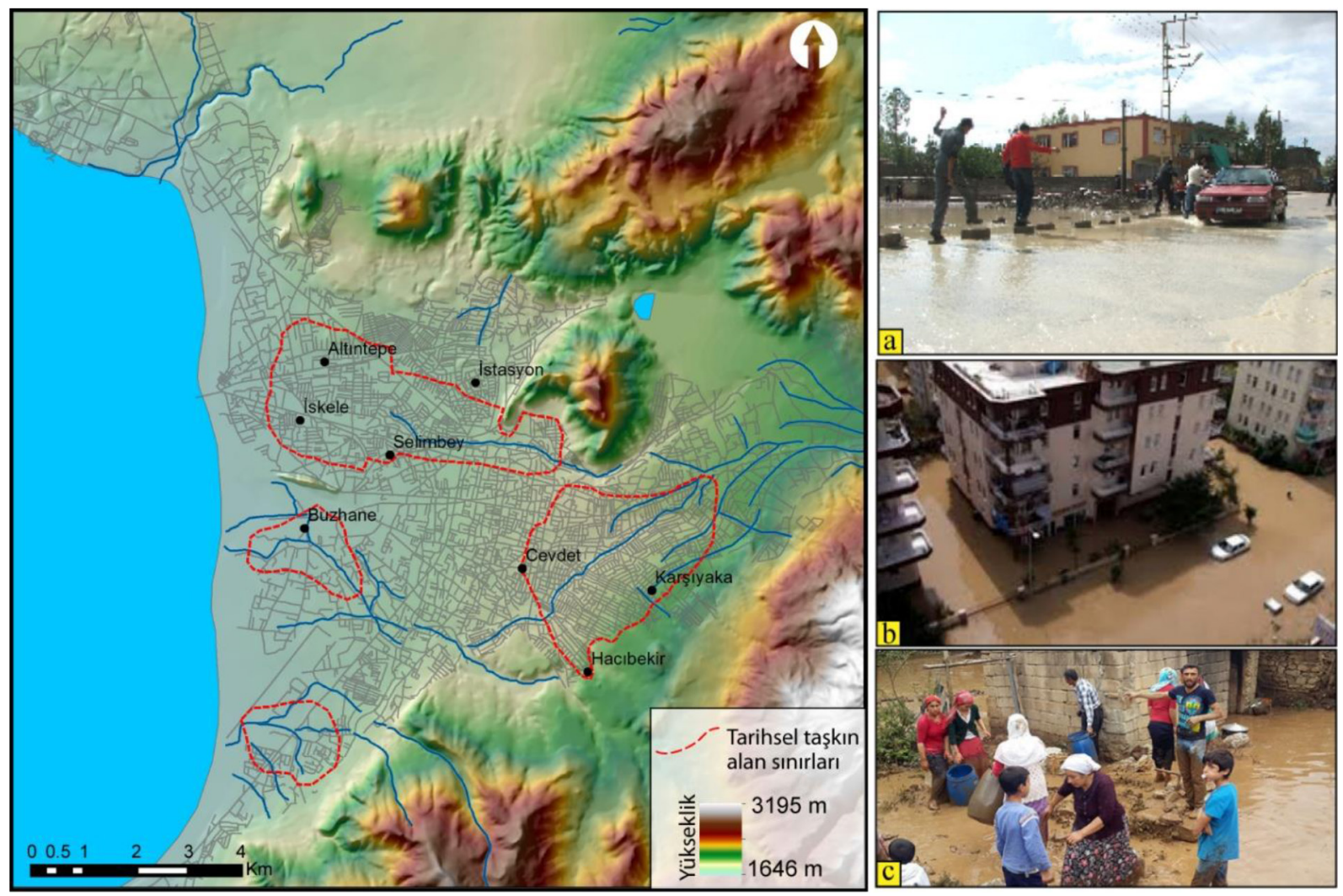

Şekil 3. Van merkez ilçeleri için tașkın alan sınırları ve bazı tașkın/su baskını olaylarının a) Ekim 2008, b) Haziran 2012, c) Mayıs 2013 tarihli görüntüleri.

Figure 3. Flood areas for Van central districts and the views of some flood events in a) October 2008, b) June 2012, c) May 2013.

kullanılarak ilçe merkezlerine ait eğim katmanı olușturulmuștur. Çalıșma alanında yapılan önceki araștırmalardan, imar paftalarından ve çalıșma kapsamında elde edilen sondaj verilerinden yararlanılarak bölgenin litoloji, yeraltı su seviyesi ve alan kullanımı gibi diğer katmanları üretilmiștir. Söz konusu her bir katman tașkın duyarlıık modelinin olușturulmasında bir kriter olarak ele alınmıștır.

Yöntemin sonraki așaması her bir CBS katmanı için ağırlık değerlerinin hesaplanmasıdır. Ağırlık değerlerinin belirlenmesinde Analitik Hiyerarși Prosesi (AHP) kullanımıștır. AHP, çok kriterli karmașık karar problemlerinin analizinde yaygın olarak kullanılan matematiksel bir yöntemdir. AHP, 1/9 (az önem derecesi) ile 9 (çok önem derecesi) değerleri arasında bir karșılaștırma ölçeği kullanarak, matris içerisinde tanımlı her bir kriterin birbiriyle kıyaslanmasına ve her bir kriter için yüzde cinsinden ağırlık değerlerinin belirlenmesine olanak tanır (Saaty ve Vargas, 1991).

AHP kendi içinde tutarlı bir sistematiğe sahip olsa da, sonuçların gerçekçiliği doğal olarak, karar vericinin kriterler arasında yaptığı birebir karșılaștırmadaki tutarlılığına bağlıdır. Dolayısıyla AHP bu karșılaștırmalardaki tutarılıı̆ın ölçülebilmesi için tutarlılık oranını (CR) önermektedir. CR, önemli kriterlerin ve dolayısıyla kriterler arasında yapılan birebir karșılaștırmaların tutarlıı̆ın test edilebilmesini sağlar. Satty (1980) tutarlılık oranını (CR) hesaplamada așağıdaki bağıntıyı önermiștir (Eșitlik (1)).

$$
C R=C I /_{R I}
$$

Burada Cl, tutarlılık değerindeki sapmayı belirleyen tutarlıık indeksi, RI ise karșılaștırmada 
Çizelge 1. Van merkez ilçelerinde meydana gelen bazı tașkın olayları (AFAD, 2015).

Table 1. Some flood events occurred in the central district of Van (AFAD, 2015).

\begin{tabular}{|c|c|c|c|c|c|}
\hline \multicolumn{2}{|c|}{ IPEKYOLU } & \multicolumn{2}{|c|}{ TUȘBA } & \multicolumn{2}{|c|}{ EDREMIT } \\
\hline YER & TARIH & YER & TARIH & YER & TARIH \\
\hline Merkez & $16 / 04 / 2003$ & Akköprü, Mh & 01/10/2008 & Süphan Mh & $30 / 09 / 2008$ \\
\hline Araștırma H & 18/09/2003 & Beyüzümü Mh & 01/10/2008 & Süphan Mh & 01/10/2008 \\
\hline Cumhuriyet Cad & 06/03/2004 & A.Gazi Mh & 01/10/2008 & Merkez & $25 / 09 / 2011$ \\
\hline Merkez & 04/06/2007 & A.Yesivi iöo & $21 / 11 / 2008$ & & \\
\hline Merkez & $14 / 06 / 2007$ & Seyrentepe Mh & 02/11/2009 & & \\
\hline Merkez & $24 / 05 / 2007$ & Akköprü Mh & 03/11/2009 & & \\
\hline Hacıbekir Mh & $30 / 09 / 2008$ & Altıntepe Mh & 03/11/2009 & & \\
\hline Karșıyaka Mh & $30 / 09 / 2008$ & E. Vakfı iöo & 03/11/2009 & & \\
\hline S. F. Arvasi, Mh & 01/10/2008 & Istasyon Mh & 09/04/2009 & & \\
\hline Yeni Mh & 01/10/2008 & Istasyon Mh & 09/03/2009 & & \\
\hline Cevdetpașa Mh & 01/10/2008 & A.Yesevi ï̈O & $11 / 04 / 2011$ & & \\
\hline Z. Hanım Cad & $23 / 10 / 2008$ & Mar. Sitesi & $27 / 04 / 2011$ & & \\
\hline Merkez & 02/11/2009 & Merkez & 04/05/2011 & & \\
\hline Merkez & $12 / 06 / 2011$ & Merkez & 02/05/2011 & & \\
\hline Merkez & $30 / 05 / 2011$ & İstasyon Mh & $25 / 06 / 2012$ & & \\
\hline Kumru Sk & $19 / 05 / 2011$ & İskele, Vatso & $20 / 05 / 2013$ & & \\
\hline Merkez & $22 / 04 / 2011$ & Altıntepe Mh & $22 / 04 / 2014$ & & \\
\hline Yeraltı Çarșısı & $20 / 05 / 2013$ & Beyüzümü Mh & $22 / 04 / 2014$ & & \\
\hline Merkez & $23 / 07 / 2014$ & & & & \\
\hline Yeni Mh & $22 / 04 / 2014$ & & & & \\
\hline Hacıbekir Mh & $22 / 04 / 2014$ & & & & \\
\hline Karșıyaka Mh & $22 / 04 / 2014$ & & & & \\
\hline Halilağa Mh & $22 / 04 / 2014$ & & & & \\
\hline Selimbey Mh & $22 / 04 / 2014$ & & & & \\
\hline Cevdetpașa Mh & $22 / 04 / 2014$ & & & & \\
\hline Yeraltı çarșısı & $01 / 05 / 2014$ & & & & \\
\hline Selimbey Mh & $16 / 02 / 2015$ & & & & \\
\hline Kale Alanı & $30 / 03 / 2015$ & & & & \\
\hline
\end{tabular}

Not: yağıș değerleri Șekil 5a' da verilmiștir. 


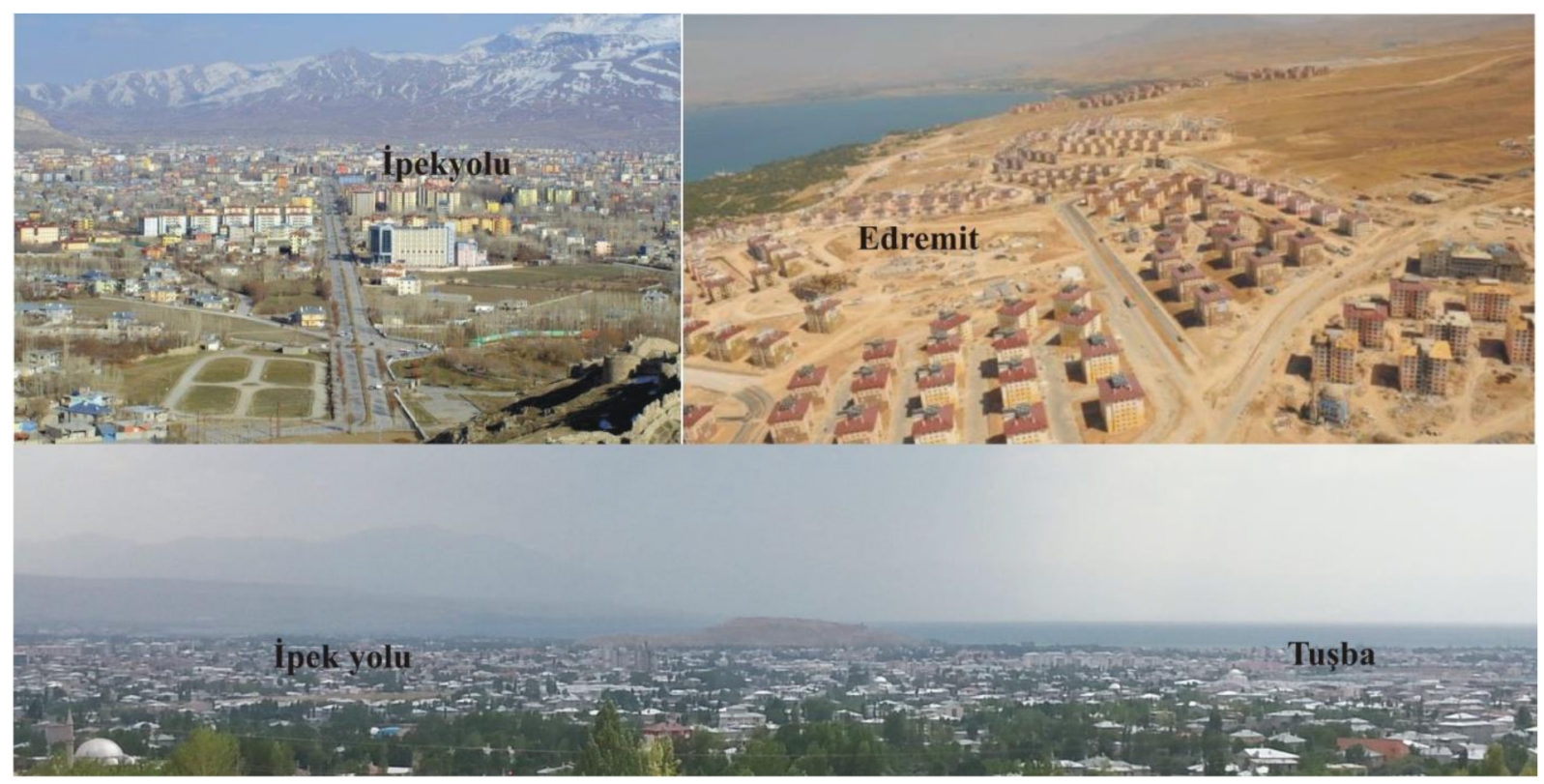

Şekil 4. Van merkez ilçeleri tanımlayan genel görüntüler.

Figure 4. General views of Van central districts.
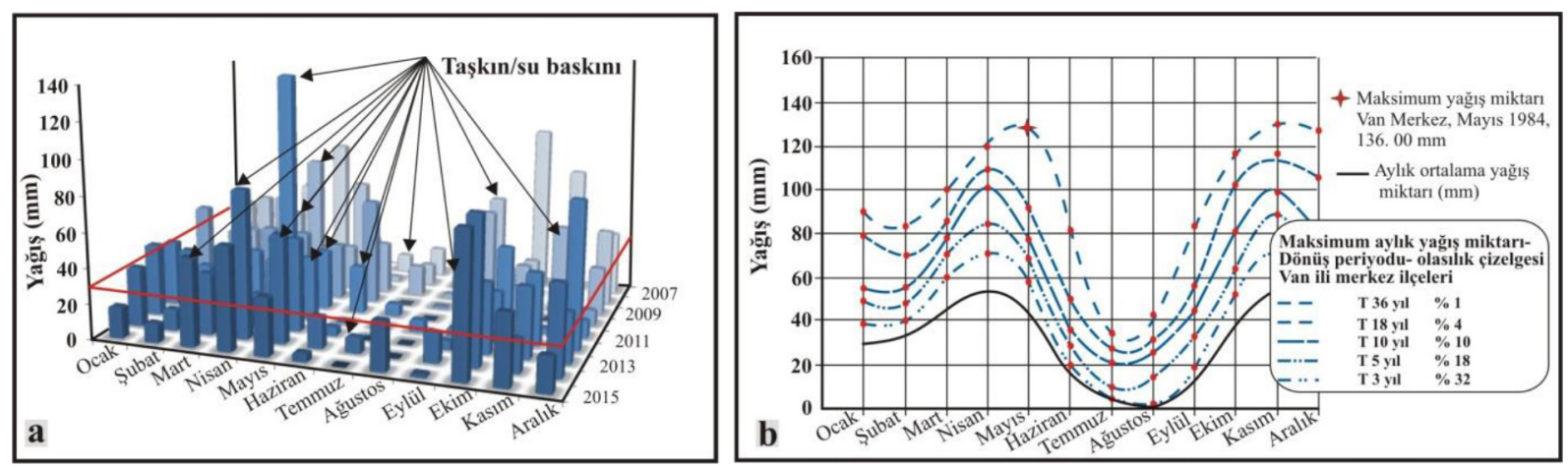

Șekil 5. a) Van merkez ilçeleri için 2007-2015 yılları arası yağıș verileri ve su baskını olayları, b) 1980-2015 yılları arası yağıș verilerine bağlı olarak hazırlanan yağıș-olasılık ve dönüș periyodu ilișkileri.

Figure 5. a) Precipitation data and flooding events between 2007 and 2015 years for Van central districts, b) precipitation, probability and return period relations obtained from 1980 -2015 years.

kullanılan kriterlerin sayısına bağlı standart düzeltme değeridir. (2) no.lu eșitlik kullanılarak tutarlılık indeksi değeri elde edilir.

$C I=\left(y_{\text {maks }}-n\right) / n-1$

Sayısal değerler açısından, kriterin önem değerlerinin ağırlık değerlerine bölümünden elde edilen eșik değeri $\left(\mathrm{y}_{\text {maks }}\right)$, her zaman karșılaștırma yapılan kriterlerin sayısına (n) eșit veya eleman sayısından büyük bir değere sahiptir. Hesaplanan CR değerinin 0.10' dan küçük olması karar vericinin yaptığı karșılaștırmaların tutarlı olduğunu gösterir. CR değerinin 0.10 değerinden büyük olması bir hesaplama hatasını ve/veya karar vericinin karșılaștırmadaki tutarsızlığını göstermektedir.

\section{FAKTÖRLERIN DEĞERLENDIRILMESi}

ÇKKA ile birbirinden farklı özelliğe sahip ve bağımsız faktörler bir arada değerlendirilir. Böylelikle, çok daha güvenilir sonuçların elde 


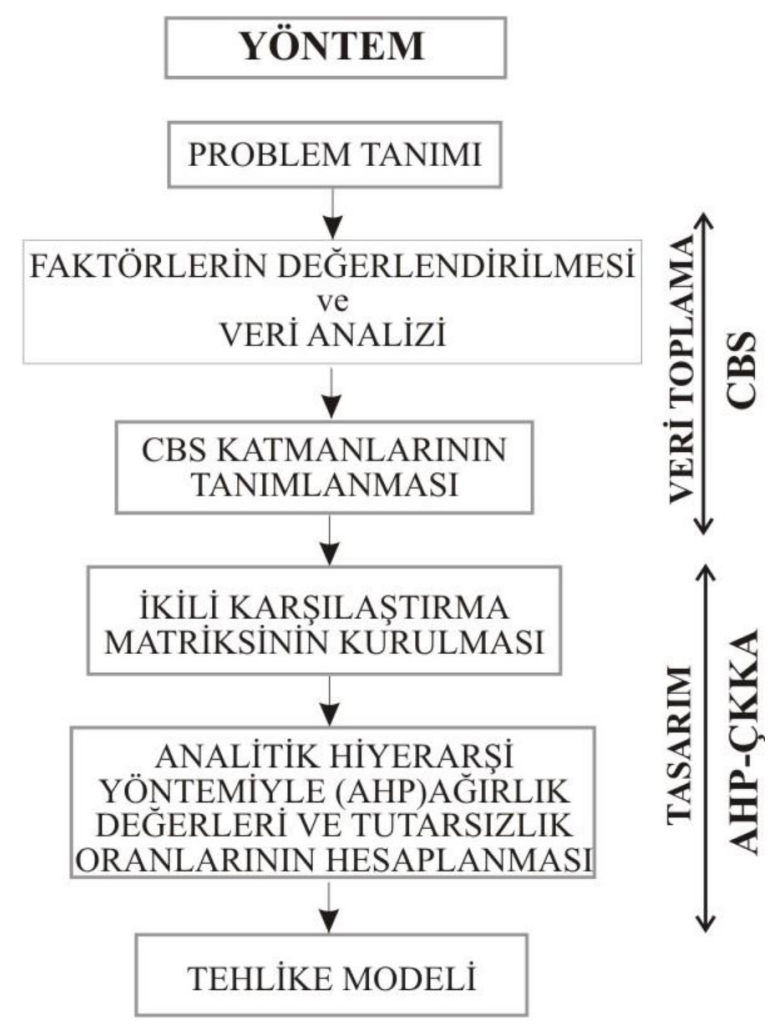

Şekil 6. Tașkın duyarlılık değerlendirmesi için akıș șeması.

Figure 6. Flowchart of procedure for flood assessment.

edilmesi ve karar verme sürecinde birden fazla alternatifin değerlendirilmesi sağlanır. Tașkın duyarlıık değerlendirmesinde, ÇKKA ile çok sayıda faktör birlikte değerlendirilmiştir. Bölgeye olan yağış miktarı ve iklimsel meteorolojik bileșenler günlük hava durumu ile ilișkilidir ve sürekli değișim gösterirler. Bu nedenle, çaIıșmada meteorolojik veriler yerine, çok daha süreklilik gösteren, șehirleșmenin hidrojeolojik etkisi ve jeolojik durum üzerinde durulmuștur. Şehirleşme süreci içerisinde, doğal jeolojik ortam geçirimsiz olabileceği gibi, bina ve yollar ile geçirimsiz yüzeylerin olușturulması da söz konusudur. Dolayısıyla, ana akıș yollarının değișmesi ve potansiyel sızma miktarının azalması tașkın tehlikesini artırır. Çalışmada tașkın duyarıılı̆ını değerlendirmek için, șehirleșme sürecine ve jeolojik duruma bağlı olan hidrojeolojik etkiler dikkate alınarak, 6 ayrı faktör içerisinde değerlendirme yapılmıștır (Şekil 7). Bu önemli faktörler, litoloji, su tablası derinliği, eğim, yükseklik, kanal mesafesi ve alan kullanımıdır. Tașkın duyarııık modelinin değerlendirilmesinde kullanılan her faktöre ait ayrıntıı bilgi așağıda verilmiștir.

\section{Eğim}

Eğim değerleri potansiyel tașkınların değerlendirilmesinde önemli bir arazi parametresidir. Literatürdeki sonuçlara göre su toplama havzaları 4 grup içerisinde değerlendirilmektedir. İlk grup arazi eğim değerlerinin $2^{\circ}$ 'den az olduğu durumdur. Bu grupta tașkın olayları topografyaya oldukça duyarlıdır. Eğim değerlerinin $2^{\circ}$ ile $6^{\circ}$ arasında olması durumunda yine topografyaya olan duyarlılık yüksektir ancak ilk gruptan daha düșük bir duyarlılık söz konusudur. Eğim değerlerinin $6^{\circ}$ ile $16^{\circ}$ arasında olması durumunda az duyarlılık söz konusu iken, eğim değerlerinin $16^{\circ}$ 'den yüksek olması durumunda taşkın parametreleri topografya için önemli değildir (Masoudian, 2009). Genellikle eğimin düșük olduğu düz alanlar yüzey akıșının düșük olduğu geçici su toplanma alanlarıdır. 

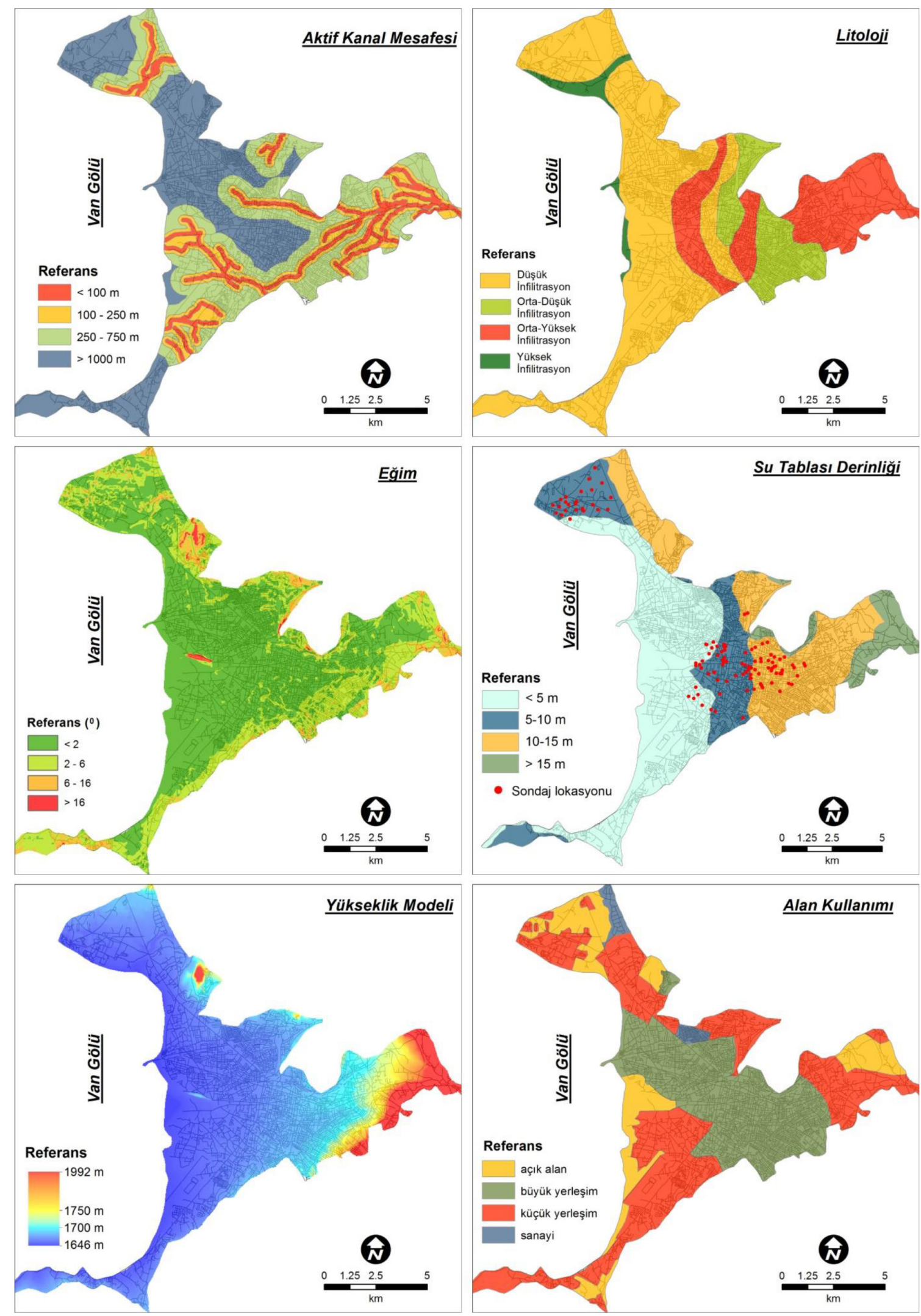

Șekil 7. Tașkınların değerlendirilmesi için CBS katmanları ve alt kriterleri.

Figure 7. GIS layers and their criteria for flood assessment. 
Çalıșma alanın genel akıș yönü doğudan batıya doğrudur. Eğim değerleri genellikle $16^{\circ}$, den batıya doğru $2^{\circ}$ arasında değișmektedir. Çizelge 2'de verildiği gibi eğim değerleri 4 grup içerisinde değerlendirilmiștir.

\section{Kanal Mesafesi}

Drenaj kanalına olan uzaklık, kent planlamasında özellikle tașkın açısından önemli bir faktördür. Çünkü yerleșim alanlarında meydana geIen tașkın olaylarında en çok etkilenen kesimler

Çizelge 2. Her bir katman içerisindeki kriterlerin ağırlık değerleri.

Table 2. Assigned weight values for criteria in each layer.

\begin{tabular}{|c|c|c|c|}
\hline Katmanlar & Ağırlık & Kriter & Değerler \\
\hline \multirow[t]{5}{*}{ Aktif kanal mesafesi } & 0.3012 & $>750$ & 0.5791 \\
\hline & & $750-250$ & 0.2326 \\
\hline & & $250-100$ & 0.1213 \\
\hline & & $<100$ & 0.0670 \\
\hline & & & Tutarsızlık oranı: $\mathbf{0 . 0 0 7 6 2 5}$ \\
\hline \multirow[t]{5}{*}{ Litoloji } & 0.2126 & Yüksek infiltrasyon & 0.6273 \\
\hline & & Yüksek-orta infiltrasyon & 0.2033 \\
\hline & & Orta-düșük infiltrasyon & 0.1084 \\
\hline & & Düșük infiltrasyon & 0.0610 \\
\hline & & & Tutarsızlık oranı: $\mathbf{0 . 0 1 2 3 5 9}$ \\
\hline \multirow[t]{5}{*}{ Eğim } & 0.2365 & $>16^{\circ}$ & 0.5923 \\
\hline & & $16^{\circ}-6^{\circ}$ & 0.2724 \\
\hline & & $6^{\circ}-2^{\circ}$ & 0.0844 \\
\hline & & $<2^{\circ}$ & 0.0508 \\
\hline & & & Tutarsızlık oranı: $\mathbf{0 . 0 1 7 8 3 1}$ \\
\hline \multirow[t]{5}{*}{ Su tablası derinliği } & 0.0842 & $>15$ & 0.6678 \\
\hline & & $15-10$ & 0.1971 \\
\hline & & $10-5$ & 0.0703 \\
\hline & & $<5$ & 0.0647 \\
\hline & & & Tutarsızlık oranı: 0.01935 \\
\hline \multirow[t]{5}{*}{ Yükseklik } & 0.0985 & $>1770$ & 0.6644 \\
\hline & & $1770-1750$ & 0.1815 \\
\hline & & $1750-1700$ & 0.0981 \\
\hline & & $<1700$ & 0.0559 \\
\hline & & & Tutarsızlık oranı: 0.016383 \\
\hline \multirow[t]{5}{*}{ Alan kullanımı } & 0.0669 & Açık alan & 0.5967 \\
\hline & & Sanayi & 0.2819 \\
\hline & & Büyük yerleșim & 0.0627 \\
\hline & & Küçük yerleșim & 0.0586 \\
\hline & & & Tutarsızlık oranı: 0.015675 \\
\hline
\end{tabular}


drenaj kanallarına yakın olan mesafelerdir (Weli ve Oye, 2014). Drenaj havzası içerisinde insan faaliyetleri, dere yatağının değiștirilmesine bağlı olarak olası su baskını potansiyelini arttırmaktadır. Çalıșmada kanal mesafe aralıkları 100 m'den küçük, 100 m ile 250 m, 250 m ile 750 m ve 750 m'den büyük olacak șekilde tampon bölgelere ayrılmıștır.

\section{Yükseklik}

Yağıș, sıcaklık ve rüzgar gibi meteorolojik faktörler yüksekliğe bağlı olarak değișim gösterirler. Genel olarak yüksek rakımlarda, yağıș tipi ve rüzgâr küresel kușaklara bağlı olarak değișim gösterirler. Özellikle düșük kotlarda nispeten sıcak hava koșullarına bağlı olarak yağıș tipi yağmur olarak yüzeye düșer. Ayrıca yükseklik, taşkın yönünün kontrolünde ve yeraltı su tablası derinliği içinde önemli bir rol oynar (Fernandez ve Lutz, 2010).

Çalışma alanı, 1650 m ile 1770 m yükseklik değerleri içerisinde değișen düșük eğimli Van Ovası üzerinde bulunmaktadır. Yükseklik değerleri doğuya doğru gidildikçe artmaktadır. Olușturulan dijital yükseklik modelinde 4 ana grup içerisinde değerlendirilme yapılmıștır. 1770 m ile 1800 m yükseklik değerleri tașkın duyarlıığının düşük olduğu en uygun yükseklik değerleridir. $1700 \mathrm{~m}$ ve daha düșük yükseklik değerleri potansiyel tașkının meydana gelebileceği uygun olmayan yükseklik değerleri olarak tanımlanmıștır. 1750 m-1770 m ve 1750 m-1700 m yükseklik değer aralıkları ise orta gruplar olarak değerlendirilmiștir.

\section{Litoloji}

Litoloji yüzey akıșını etkilemesi nedeniyle önemli bir faktördür. Örneğin karstik bir yapı ani taşkın olușumunu engellerken, düșük geçirgenliğe veya infiltrasyona sahip filiș veya Neojen yașlı sedimanlar tașkın duyarılıı̆ını arttırmaktadır (Bonacci vd., 2006; Kourgialas ve Karatzas, 2015). Çalıșmada sondaj verileri kullanılarak Plio-Kuvaterner yașlı sedimanların geçirgenlik değerleri dikkate alınarak 4 ana grup içerisinde değerlendirilme yapılmıștır. Bu gruplar yüksek infiltrasyon (SP), yüksek-orta infiltrasyon (SM), orta-düșük infiltrasyon (ML-MH) ve düșük infiltrasyon $(\mathrm{CL}-\mathrm{CH})$ olarak değerlendirilmiștir.

\section{Su Tablası Derinliği}

Sızma kapasitesi yeraltı suyunun derinliğinden etkilenir. Özellikle ilkbahar aylarında yağışların artması ve karların erimesine bağlı olarak yeraltı su seviyesi yüzeye yaklașmakta ve zemin doygun hale gelmektedir. Bu durum söz konusu akıș miktarını da artırmaktadır. Havzanın depolama kapasitesinin belirlenmesinde, efektif su tablası derinliğinin bilinmesi gerekliliğine birçok çalıșmada değinilmiștir (Trosh vd.,1993; Yin ve Li, 2001; Fernandezve Lutz, 2010). Bu çalıșmada elde edilen yeraltı su tablası derinlikleri, mahalle bazında yapılan sondaj çalışmaları ile bölgede önceki dönemlerde yapılan jeolojik ve hidrojeolojik çalışmalardan elde edilen verilerin birlikte korele edilmesiyle olușturulmuștur. Ancak çalıșma alanının litolojik ve benzer olarak hidrojeolojik parametreleri anlık olarak değișkenlik sergileyebilmektedir. Özellikle veri yetersizliği olan alanlarda yapılan kısıtlı sayıdaki çaIıșmalardan elde edilen verilerin süreklilik gösterdiği kabul edilmiștir (Şekil 7). Çalışmada 15 m'den daha derinde bulunan yeraltı su tablası değerleri tașkın tehlikesinin düşük duyarlıığa sahip olduğu bir kriter olarak değerlendirilmiștir. 0 ile $5 \mathrm{~m}$ arasında değișen yeraltı su seviyesi değerleri ise tașkın için elverișli koșullar sağlamaktadır. $5 \mathrm{~m}$ ile $10 \mathrm{~m}$ ve $10 \mathrm{~m}$ ile $15 \mathrm{~m}$ derinlikler ise diğer kriterler olarak değerlendirilmiștir.

\section{Alan Kullanımı}

Bina, yol, otopark gibi asfaltlanmıș alanlar zeminin sızma kapasitesini ve akıș miktarını önemli ölçüde etkilemektedir. Șehirleșmede tipik olarak yüzey suyu ve tahliye edilecek suyun miktarı artmaktadır. Söz konusu mahallelere ait alan kullanım sınıflaması, șehir imar planı dikkate alınarak yapılmıștır. Burada sayısal değerler olarak hektar bașına düșen konutların sayısı dikkate alınmıștır. Bu aynı zamanda șehrin yoğunluk (R) kodunu olușturmaktadır. Örneğin R35 hektar bașına 35 konut demektir. Her yoğunluk kodu da minimum veya ortalama taban alanı gereksinimlerini getirir. Bu değerler uluslararası tasarım kodları içerisinde tanımlıdır. Van için ortalama 
olarak R17 yoğunluk kodu hesaplanmıștır. Bu kod değeri azami $500 \mathrm{~m}^{2}$ gereksinimini sunmaktadır. Elbette ki bu ortalama değer, șehrin cazibe noktalarına veya mahallelerine bağlı olarak değișmektedir. Bu değerden daha küçük olan alanlar daha yoğun yapılașmanın olduğu, daha büyük değerler ise seyrek yapılașmanın olduğu alanları tanımlar. Buna göre çalıșma alanı; açık alanlar (tarım ve park alanları), sanayi (ticari ve iș merkezleri), büyük $\left(<500 \mathrm{~m}^{2}\right)$ ve küçük (>500 $\mathrm{m}^{2}$ ) yerleșim alanları olmak üzere 4 ayrı bölge içerisinde değerlendirilmiștir.

\section{DUYARLILIK MODELININ OLUȘTURULMASI}

6 ayrı CBS kriteri ve her CBS katmanı içerisinde tanımlı faktörlerin ağırlık değerleri ikili karșılaștırma matrisi temel alınarak belirlenmiștir. İkili karșılaștırma matrisleri olușturulurken, yukarda tanımlı her bir kriterin önem derecesi mühendislik bakıș açısı içerisinde değerlendirilmiștir. Karșlaștırma matrisleri içerisinde elde edilen her bir katman içerisinde tanımlı faktörlerin ağırlık değerleri Çizelge 2'de verilmiștir. Karșılaștırma matrislerinden elde edilen tutarsızlık oranı (CR) değerleri, Saaty (1980) tarafından önerildiği gibi 0,10 değerinden küçüktür.

Her bir kriterin ağırlık değeri, CBS katmanlarında tanımlı gerçek veriye bağlı olarak değerlendirilmektedir. Ancak, (AHP) içerisinde kriterlerin önem derecesi, bu konuda uzman kișinin mühendislik yargısına bağlı olduğundan dolayı oldukça sübjektiftir. Bu kișisel yargıyı önlemek için, Çizelge-3'de görüldüğü gibi her bir katman için ağılık değerlerinin belirlenmesinde, bölgeyi tanıyan, konusunda yeterli bilgi ve beceriye sahip farklı uzmanların önem dereceleri hakkındaki değerlendirmeleri dikkate alınmıștır. Tașkın duyarlıık değerlendirmesinde uzmanların vermiș olduğu yüksek önem dereceleri aktif kanal mesafesi ve eğim katmanları üzerinedir. Bu katmanların ağırlık değerleri diğer katmanlara oranla daha yüksektir. Litoloji katmanı üzerinde ise genel olarak uzmanlar eșit derecede bir değerlendirmede bulunmușlardır. Diğer CBS katmanları ise (yükseklik, su tablası derinliği ve alan kullanımı) göreceli olarak daha az önem derecesine sahiptir. Modelin olușturulmasında her bir kriter için uzmanlar tarafından verilen ağırlık değerlerinin ortalaması kullanılmıștır. Ortalama ağırlık değerlerine göre söz konusu faktörlerin önem sırası; aktif kanal mesafesi, eğim, litoloji, yükseklik, su tablası derinliği ve alan kullanımı șeklindedir.

Çalışmada her bir CBS katmanı kendi içerisinde alt kriterlere ayrılmıștır. Dolayısıyla, tașkın modelinin elde edilmesinde 6 ayrı CBS katman içerisinde, tanımlı 24 ayrı kriterin ağırlık değerlerinin belirlenmesi gereklidir. Söz konusu modelin olușturulmasında kriterlerin ağılık değerleri așağıdaki ilișki ile belirlenmiștir.

$$
\mathrm{H}_{\mathrm{i}}=\Sigma \mathrm{w}_{\mathrm{i}} \mathrm{x}_{\mathrm{i}}
$$

Çizelge 3. 4 ayrı uzmana göre Van il merkezinde tașkın duyarııı̆ı için CBS katmanlarının ağırlık değerleri. Table 3. Assigned weight values of GIS layers for flood susceptibility in Van city according to 4 experts.

\begin{tabular}{|c|c|c|c|c|c|}
\hline CBS katmanları & Yazarlar & Uzman A & Uzman B & Uzman C & Ortalama \\
\hline Aktif kanal mesafesi & 0.4872 & 0.1347 & 0.1244 & 0.4587 & 0.3012 \\
\hline Litoloji & 0.2287 & 0.2035 & 0.1244 & 0.2941 & 0.2126 \\
\hline Eğim & 0.1289 & 0.3653 & 0.3641 & 0.0877 & 0.2365 \\
\hline Su tablası derinliği & 0.0638 & 0.0809 & 0.1244 & 0.0675 & 0.0841 \\
\hline Yükseklik & 0.0503 & 0.0809 & 0.212 & 0.0508 & 0.0985 \\
\hline Alan kullanımı & 0.0411 & 0.1347 & 0.0507 & 0.0412 & 0.0669 \\
\hline Tutarsızlık Oranı(CR) & 0.016279 & 0.012376 & 0.009876 & 0.015271 & 0.0134505 \\
\hline
\end{tabular}


Burada, $H_{i}$ model haritanın piksel ağırlık değeridir. $w_{i}$ her bir CBS katmanı için belirlenen ağırlık değeri, $x_{i}$ ise her bir CBS katmanında tanımlı alt kriterlerin (i) ağırlık değeridir.

Çalışma alanı için oluşturulan duyarlılık modeli 5 ayrı bölgeye ayrılmıștır (Şekil 8); Yüksek Duyarlılık, Yüksek-Orta Duyarlılık, Orta Duyarlıık, OrtaDüșük Duyarlııık ve Düșük Duyarlılık. Modelde bölgelerinin sınır ağırlık değerleri belirlenirken, doğal kesiklik sınıflaması (Natural Breaks Classification) yöntemi kullanılmıștır. Jenks optimizasyonu olarak bilinen yöntem, veriyi en ideal ayrım ile sınıflara ayırmaktadır. Yöntemdeki sınır değerlerin elde edilmesinde, her sınıfta gözlenen değerler ile ortalama değerler arasındaki farkların kareler toplamlarının tekrarlı karșılaștırması dikkate alınmaktadır (Jenks, 1967). Bölgeleri tanımlayan bu sınır değerlerin uygunluğu, söz konusu faktörlerin önem derecesine bağlı olarak ayrıca değerlendirilmiștir.

\section{BULGULAR ve TARTIȘMA}

Tașkın duyarlılık modelinin olușturulmasında CBS tabanlı ÇKKA yöntemi kullanılmıștır.

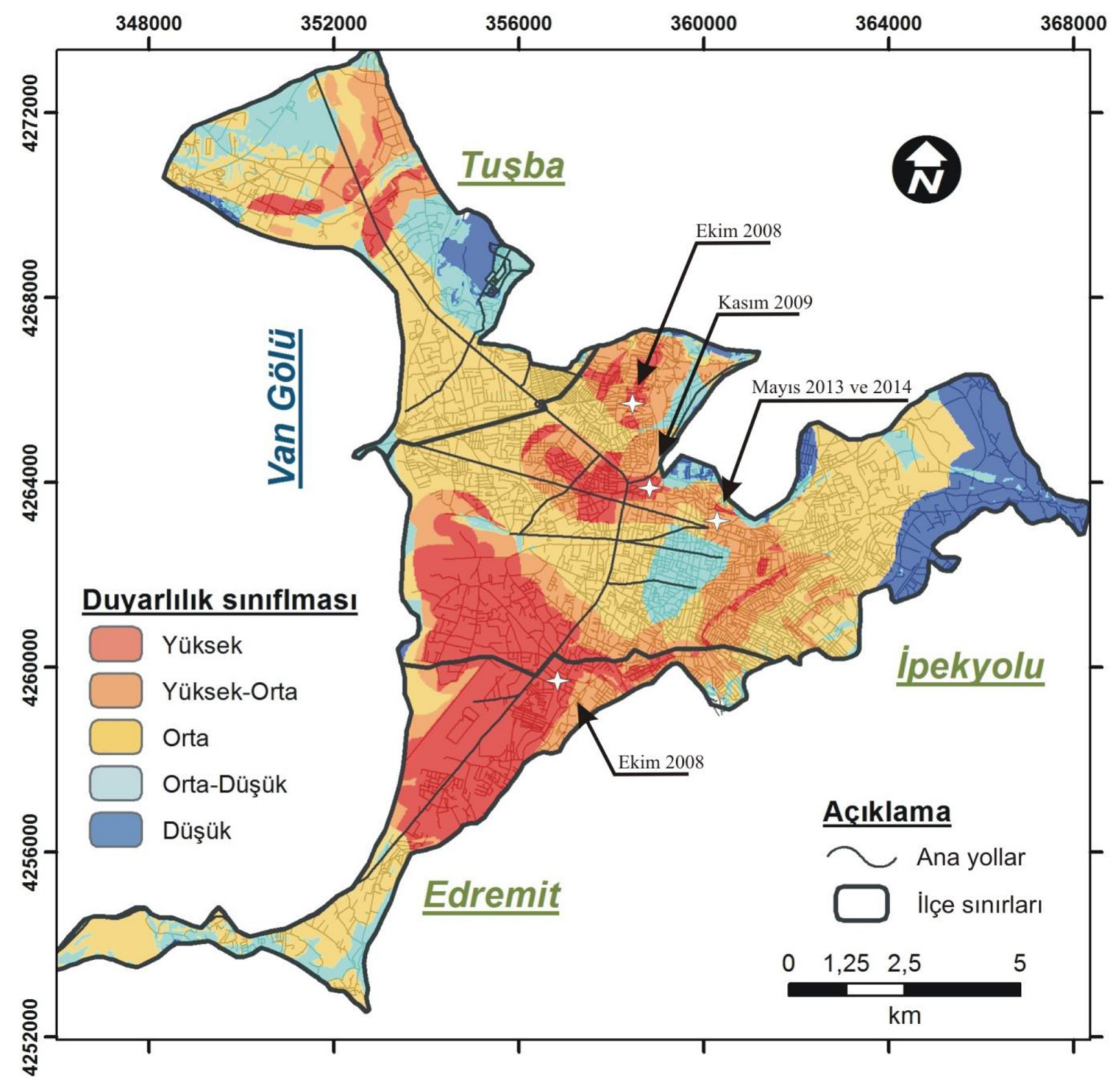

Șekil 8. Çalıșma alanının tașkın duyarlıık modeli.

Figure 8. Flood susceptibility model of the study area. 
Yöntem birçok faktörün birlikte değerlendirilmesinde ortaya çıkan problemlerin pratik olarak çözümlenmesinde yaygın olarak kullanılmaktadır. Ayrıca kriterlerin ağırlık değerlerinin belirlenmesinde ve çok sayıdaki verinin bütünleștirilmesinde yöntemin kapasitesi ve kolaylığı, doğal afetlerin farklı faktörler içerisinde değerlendirilmesine olanak tanımaktadır.

Bu kapsamda olușturulan duyarlılık modelinde, İpekyolu ilçesi yüksek duyarlı alanları içermektedir. Yüksek duyarlı alanlar İpekyolu merkez ilçesinin toplam alanının yaklașık \% 20'sini olușturmaktadır. Söz konusu ilçede tașkın duyarlılığının çok yüksek olduğu mahalleler Hatuniye, Buzhane, Alipașa, S.Fehim Avrasi, Yeni mahalle ve Cevdetpașa mahalleleridir. Tașkının yüksek olduğu mahalleler ise Selimbey, Yalı, Cumhuriyet ve Esenler mahalleleridir. Tașkın duyarlılığının orta ve düșük olduğu mahalleler ise Șerefiye ve Serhat mahalleleridir. Tușba ilçesinde ise Akköprü, İstasyon, Beyüzümü, Altıntepe ve Abdurrahman Gazi mahalleleri yüksek duyarIı bölgeler içerisinde yer alırken, Edremit ilçesinde Șabaniye ve Süphan mahalleleri dıșında genellikle orta ve kısmen düșük duyarlılık söz konusudur. 3 ayrı merkez ilçe dikkate alındığı zaman, yüksek duyarlı alanlar toplam alanın \% 19.9'unu olușturmaktadır. Yüksek-orta ile orta duyarlı alanlar ise sırasıyla toplam alanın \% 18.4 ve \% 39.8'ini olușturmaktadır. Bu değerler merkez ilçelerin önemli bir bölümünün olası bir tașkın olayında yüksek derecede etkilenebileceğini göstermektedir. Nitekim olușturulan modelde yüksek duyarlılığa sahip mahallelerin büyük bir kesimi 1 Ekim 2008 ve Kasım 2009 tarihlerinde meydana gelen tașkın olaylarından așııı derecede etkilenmiștir (AFAD, 2015). Dolayısıyla, tașkın potansiyeli yüksek olan bölgelerde yaşayan insanların güvenliği ve tașkın olaylarına karșı etkin bir planlama için, olușturulan duyarllık modeli yararı bilgiler sağlayabilir. Bu kapsamda yapılacak olan uygulamalarda öncelik bu alanlarda, yoğunluğun fazla olduğu idari merkezlere verilmelidir.

Geliştirilen model, tașkından etkilenen alanlar ile karșılaștırıldığı zaman tutarlı sonuçlar sağlamaktadır (Şekil 8). Ayrıca modelde olası bir tașkın olayında çok daha geniş alanların yüksek derecede etkilenebileceği görülmektedir. Bu durum oluşturulan modelin çok sayıdaki faktörü birlikte değerlendirmesinden kaynaklanmaktadır. Her ne kadar modelde aktif kanal mesafesi ve eğim önemli faktörler olsa da, merkez ilçelerindeki jeolojik durum, alan kullanımı, yeraltı su tablası derinliği ve yükseklik değerleri de tașkın duyarııı̆ını tanımlamada gerçeğe yakın sonuçların elde edilmesini sağlamıștır. Söz konusu bu faktörler modelde tanımlı yüksek duyarlı bölgelerin çok daha geniș alanlar kaplayabileceğini göstermiștir.

Olușturulan duyarlılık modeli genelleștirilmiș bir yöntemi uygulayarak dijital formda olușturulmuștur. Dolayısıyla, veri yetersizliği olan alanlarda güncellenerek, bu kapsamda çalıșan kurum ve kurulușlar arasında paylașım yapılarak çok daha sağlıklı değerlendirmelerin elde edilmesi sağlanabilir. Ayrıca ülkemizin jeolojik, jeomorfolojik yapısı ve sahip olduğu iklimsel özellikleri her an can ve mal kaybına yol açabilecek doğal afetlerle karșılașmasına neden olmaktadır. Dolayısıyla bu çalıșmadan elde edilen sonuçların ve kullanılan yöntemin, meteorolojik parametrelerle birlikte yeniden değerlendirilmesiyle, henüz uygulama alanı bulamamıș yerleșim alanlarında "Planlı Kentleșme" kavramına mühendislik jeolojisi açısından bir çözüm sağlayabileceği de açıkça görülmektedir.

\section{SONUÇLAR}

Van ili merkez ilçelerinin tașkın duyarlılık değerlendirmesi, bölgenin jeolojik, jeomorfolojik ve alan kullanımı dikkate alınarak CBS tabanlı olarak dijital ortamda gerçekleștirilmiștir. Aktif kanal mesafesi, jeolojik durum ve eğim değerleri, tașkın duyarlıığını değerlendirmede önemli faktörler olarak ele alınmıștır. Olușturulan modele göre, yüksek ve yüksek-orta duyarlı alanlar, toplam alanının \% 39'unu olușturmaktadır. Yüksek ve yüksek-orta duyarlılığa sahip alanlar, bölgede meydana gelen tașkın olayları ile oldukça uyumludur. Bu alanlar özellikle İpekyolu ilçesinin kuzeydoğu ve güneybatı mahalleleri ile Edremit ve Tușba ilçelerinin kuzeydoğu mahalleleridir. Bu alanlar özellikle ana drenaj kanalına yakın olup, aynı zamanda düșük eğimli ve litolojik olarak geçirimsiz birimler üzerinde yer almaktadır. İpekyolu ilçesinin merkez kesiminde 
șehir yașamı oldukça yoğundur. Bu alanlarda bina ve yol gibi drenaja kapalı yüzeylerin geniș bir alan kaplaması, özellikle bahar aylarında așırı yağıșlarla birlikte su baskını olaylarının sıklıkla gelișmesine neden olmaktadır.

Çalışmada uygulanan yöntem doğal afetlere karşı güvenilir ve sağlıklı bilgilerin elde edilmesine olanak sağlamıștır. Bu kapsamda üretilen duyarlılık modeli, özellikle yüksek duyarlı alanlarda, tașkına karșı yapılacak olan uygulamaların çok daha planlı ve sağlıklı bir şekilde yürütülmesinde önemli rol oynayacaktır. Ayrıca modelin olușturulmasında, veri yetersizliği olan alanlarda güncellenerek ve/veya bu kapsamda çalıșan kurum ve kurulușlar arasında paylașım yapılarak çok daha sağlıklı değerlendirmelerin elde edilmesi mümkündür. Olușturulan duyarlılık modeli tașkın afetlerinde ilk așamada meydana gelebilecek olan tehlikenin boyutlarını değerlendirmek amacıyla ilgili kurum ve kurulușlar tarafından kullanılmalıdır. Bu kapsamda güvenilir yağıș ve akıș verileri ile birlikte çok daha güvenilir tehlike modellerinin olușturulması sağlanabilir.

\section{KATKI BELIRTME VE TEȘEKKÜR}

Yazarlar bu çalıșma kapsamında, değerli görüșlerinden dolayı, Doç.Dr. Harun Aydın'a (Yüzüncü yıl Üniversitesi, Çevre Mühendisliği Bölümü), Yrd.Doç.Dr. Serkan Üner'e (Yüzüncü Yıl Üniversitesi, Jeoloji Mühendisliği Bölümü) ve Yrd.Doç. Dr. Turgay Beyaz'a (Pamukkale Üniversitesi, Jeoloji Mühendisliği Bölümü) ve makalenin değerlendirilme așamasında öneri ve düzeltmeleri ile katkı sağlayan hakem Dr. İbrahim Uçar'a ve ismi belirtilmeyen diğer hakemlere teșekkürlerini sunarlar.

\section{KAYNAKLAR}

AFAD (Afet ve Acil Durum Yönetimi Bașkanlığı), 2008. Türkiye'de afetlerin mekansal ve istatistiksel dağılımı afet bölgeleri envanteri (Editörler; Oktay Gökçe, Șenay Özden ve Ahmet Demir), Ankara, 127 sayfa.

AFAD (Afet ve Acil Durum Yönetimi Bașkanlığı), 2015. Türkiye ulusal afet arșivi, https:// tuaatest.afad.gov.tr/main.jsp, 15 Mart 2015.

Ayalew, L., Yamagishi, H., and Ugawa, N., 2004. Landslide susceptibility mapping using GIS-based weighted linear combination: The case in Tsugawa area of Agano River. Landslides, 1, 73-81.

Bonacci, O., Ljubenkov, L. and Roje-Bonacci, T., 2006. Karst flash floods: an example from the Dinaric karst (Croatia). Natural Hazards and Earth System Sci. 6 (2), 195-203.

Büchele, B., Kreibich, H., Kron, A., Thieken, A., Inringer, J., Oberle, P., Merz, B., and Nestmann, F., 2006. Flood-riskmapping: contributions towards an enhanced assessment of extreme events and associated risks. Natural Hazards and Earth System Sciences, 6, 485-503.

Dai, F.C., Lee, C.F., and Zhang, X.H., 2001. GISbased geo-environmental evaluation for urban land-use planning: a case study. Engineering Geology, 61, 257-271.

Gamper, C., Thoni, M., and Weck-Hannemann, $\mathrm{H}$., 2006. A conceptual approach to the use of cost benefit and multi criteria analysis in natural hazard management. Natural Hazards and Earth System Science, 6, 293-302.

Fernandez, D.S., and Lutz, M.A., 2010. Urban flood hazard zoning in Tucuman Province, Argentina, using GIS and multicriteriadecision analysis. Engineering Geology, 111, 90-98.

Harris, E., and Rantz, S., 1964. Effects of urban growth on stream flow regimes of Permanente Creek, Santa Clara County, California. USGS WSP 1591B.

Jenks, G.F., 1967. The Data Model Concept in Statistical Mapping. International Yearbook of Cartography, 7, 186-190.

Joerin, F., Theriault, M., and Musy, A., 2001. Using GIS and outranking multicriteria analysis for land-use suitability assessment. International. Journal of Geographical Information Science, 15, 153-174.

Kalelioğlu, E., 1991.Van Ovasının İklim Özellikle- 
ri.Ankara Üniversitesi Dil ve Tarih-Coğrafya Fakültesi Dergisi, 35 (2), 155-166.

Kolat, C., Doyuran, V., Aydan, C., and Suzen, L.M., 2006. Preparation of a geotechnical microzonation model using Geographical Information Systems based on multicriteria decision analysis. Engineering Geology, 87, 241-255.

Konrad, C.P., and Booth, D.B., 2002. Hydrologic trends associated with urban development in western Washington streams, United States Geological Survey Water-Resources Investigations Report 02-4040. Tacoma, Washington.

Konrad, C.P., and Booth, D.B., 2005. Hydrologic changes in urban streams and theirecological significance. American Fisheries Society Symposium, 47, 157-177.

Kourgialas, N. N., and Karatzas, G. P., 2011. Flood management and a GIS modelling method to assess flood-hazard areas - a case study. Hydrological Sciences Journal 56 (2), 212-225.

Malczewski, J., 2006. GIS-based multicriteria decision analysis: a survey of the literature. International Journal of Geographical Information Science, 20, 703-726.

Masoudian, M., 2009. The topographical impact on effectiveness of flood protection measures, Ph.D. thesis, , Kassel University.

MGM (Meteoroloji Genel Müdürlüğü), 2015. Resmi istatistikler, http://www.mgm. gov.tr/veridegerlendirme/il-ve-ilceleristatistik.aspx\#sfU, 16 Nisan 2015.

Saaty, T.L., and Vargas, L.G., 1991. Prediction, Projection and Forecasting.Kluwer Academic Publisher, Dordrecht.

Saaty, T.L., 1980. The Analytical Hierarchy Process. McGraw-Hill, New York.

Selçuk, L., 2013. An avalanche hazard model for Bitlis Province, Turkey, using GIS based multicriteria decision analysis. Turkish Journal of Earth Science, 22, 523-535

TiK (Türkiye İstatistik Kurumu), 2015. Temel İstatistiksel veriler, Nüfus ve Demografi, http://www.tuik.gov.tr/UstMenu. do?metod=temelist, 30 Nisan 2015.

Trosh, P., De Trosh, F., and Brutsaert, W., 1993. Effective water table depth to describe initial conditions prior to storm rainfall in humid regions. Water resources research 29 (2), 427-434.

Weli, V.E., and Oye, I., 2014. The Effect of Urbanization on Channel Adjustment and Flood Vulnerability of Woji Basin, River State, Nigeria. Journal of Natural Sciences Research. 4 (10), 86-94.

Yin, H., and Li, C., 2001. Human impacts on floods and flood disasters on the Yangtze River. Geomorphology 41 (2-3), 105109. 
